\title{
Neural Transplantation in Parkinson's Disease
}

\author{
V. Mehta, J. Spears and I. Mendez
}

\begin{abstract}
Parkinson's disease is a neurodegenerative disorder that affects about $1 \%$ of Canadians between the ages of fifty and seventy. The medical management for these patients consists of drug therapy that is initially effective but has limited long term benefits and does not alter the progressive course of the disease. The recalcitrance of longstanding Parkinson's disease to medical management has prompted the use of alternative surgical therapies. Many neurosurgical procedures have been utilized in order to improve the disabling symptoms these patients harbour. Although most of the current procedures involve making destructive lesions within various basal ganglia nuclei, neural transplantation attempts to reconstitute the normal nigrostriatal pathway and restore striatal dopamine. The initial success of neural transplantation in the rodent and primate parkinsonian models has led to its clinical application in the treatment of parkinsonian patients. Currently, well over one hundred patients throughout the world have been grafted with fetal tissue in an effort to ameliorate their parkinsonian symptoms. Although the results of neural transplantation in clinical trials are promising, a number of issues need to be resolved before this technology can become a standard treatment option. This review focuses on the current status of neural transplantation in Parkinson's disease within the context of other surgical therapies in current use.
\end{abstract}

\begin{abstract}
RÉSUMÉ: Transplantation de cellules nerveuses dans la maladie de Parkinson. La maladie de Parkinson est une affection neurodégénérative qui atteint à peu près $1 \%$ des canadiens entre l'âge de 50 et de 70 ans. Le traitement médical de ces patients consiste à administrer une médication qui est efficace dans les premiers stades de la maladie, mais qui a des bénéfices limités à long terme et qui ne modifie pas la progression de la maladie. La résistance au traitement médical de la maladie de Parkinson établie de longue date a suscité l'utilisation de traitements chirurgicaux d'appoint. Plusieurs interventions neurochirurgicales ont été utilisées afin d'améliorer les symptômes invalidant chez ces patients. Bien que la plupart des techniques utilisées actuellement impliquent de pratiquer une lésion destructrice dans divers noyaux, les tentatives de transplantation sont effectuées dans le but de reconstituer la voie nigrostriée normale et de rétablir la dopamine striatale. Le succès initial de la transplantation de cellules nerveuses chez des modèles de rongeurs et des primates parkinsoniens ont abouti à l'application clinique de ce mode de traitement chez des patients parkinsoniens. Actuellement, plus de cent patients à travers le monde ont eu une greffe de tissus foetaux dans le but d'améliorer leurs symptômes parkinsoniens. Bien que les résultats de la transplantation de cellules nerveuses au cours des essais cliniques soient prometteurs, un certain nombre de questions doivent être résolues avant que cette technologie ne devienne une option de traitement standard. Cette revue se concentre sur le statut actuel de la transplantation dans la maladie de Parkinson dans le contexte des autres traitements chirurgicaux d'usage courant.
\end{abstract}

Can. J. Neurol. Sci. 1997; 24: 292-301

Parkinson's disease (PD) is one of the most prevalent neurodegenerative diseases in Canada affecting over 100,000 patients. This progressive neurodegenerative disorder is characterized by the loss of dopamine-containing cells in the substantia nigra which leads to the ever-increasing incapacitation of patients, culminating in death. The current treatment is primarily based on dopamine replacement using the dopamine precursor L-dopa. Replacement therapy is very effective in the early stage in controlling the symptoms of PD. Unfortunately chronic Ldopa treatment may lead to mental changes, dyskinesias, and the "on-off" phenomenon. In addition, the disease progresses despite drug therapy. The onset of L-dopa-induced dyskinesias is related to many factors, including individual susceptibility as well as the length and dosage of L-dopa used. The incidence of L-dopa-induced dyskinesias is anywhere from 25 to $75 \%$ at 3 years. ${ }^{1,2}$ The dyskinesias consist of many abnormal movements including chorea, dystonia, myoclonus and hemiballismus. The "on - off" syndrome consists of rapid oscillations between a state of relatively normal mobility to a state of akinesia. The recalcitrance of $\mathrm{PD}$ to chronic medical treatment has reintroduced neurosurgery into the treatment of these patients. A number of surgical alternatives are currently in use that range from lesioning different sites within the basal ganglia to the insertion of stimulating electrodes into the subthalamic nucleus, thalamus

From the Neural Transplantation Laboratory, Department of Surgery, Division of Neurosurgery, Dalhousie University, Halifax.

RECEIVED DECEMBER 5, 1996. ACCEPTED IN FINAL FORM MARCH II, 1997. Reprint requests to: Ivar Mendez, Neural Transplantation Laboratory, Room 12D, Sir Charles Tupper Medical Building, Dahousie University, Halifax, Nova Scotia, Canada B3H $4 \mathrm{H} 7$ 
and globus pallidus. Ultimately, the best treatment for PD would be the restoration of the nigrostriatal synaptic circuitry and the replenishment of striatal dopamine. Neural grafting theoretically makes the most logical attempt at this goal. ${ }^{3-9}$ The present review will update the readership on the current status of fetal transplantation in the management of parkinsonian patients.

\section{Historical Highlights}

The history of neural grafting is over one hundred years old. Thompson in 1890 attempted grafting cat neocortex into the occipital cortex of dogs. ${ }^{10}$ His crude method of measuring outcome did not show neuronal survival; however, he observed that glial elements survived the transplantation process. In 1905, Saltykow presented the first detailed description of neural grafting of brain tissue in rabbits. ${ }^{11}$ He showed survival of neurons up to eight days after transplantation. Clear survival of grafted neurons from 9-10 day old rats into cortical cavities of littermate hosts was first reported by Dunn in 1917.12 Le Gros Clark in 1940 , proposed that fetal grafts had the best potential to reestablish host architecture. ${ }^{13}$ In 1945, May cografted muscle and cerebellum and showed that the muscle received fibre growth from the cerebellar graft. This supported the notion that grafts were able to innervate adjacent tissue. ${ }^{14}$

Flenko and Szentagothai in 1957, implanted ovarian and pituitary tissue into the vicinity of the third ventricle. ${ }^{15}$ This experiment was the basis for further research in pituitary gland grafts into the mediobasal hypothalamus of hypophysectomized rabbits. These grafts reversed endocrine deficiency within the rats and demonstrated for the first time graft-induced functional effects in the host..$^{16,17}$

By the mid 1970s following the work of Das, Lund and Hauscha, and Björklund and colleagues it became clear that fetal grafting was able to reconstitute neural circuitry. ${ }^{18-24}$ Björklund demonstrated that ventral mesencephalic (VM) tissue of 16-19 day old embryonic rat donors implanted into a created cavity within the parietal cortex of a 6-hydroxydopamine (6OHDA) lesioned rodent reinervated the host neostriatum.

In 1979, Perlow et al. grafted fetal nigral cells into the striatum of lesioned rats. ${ }^{25}$ These nigral grafts were compared to sciatic nerve grafts and showed that only the nigral grafts induced functional rotational recovery in the lesioned animal. This group also demonstrated long term survival of fetal nigral grafts and continued functional effects over a ten month period. ${ }^{26}$ In 1981 , Freed and collaborators demonstrated that adrenal medullary cells also produce functional improvement when grafted into the neostriatum of a lesioned rat. ${ }^{27}$

During the same period, non-human primate models were being developed, as the rodent model only partially represented the complexity of human clinical parkinsonism. The primate models more effectively demonstrated human parkinsonian features like tremor, rigidity and bradykinesia. The success of fetal grafting in the parkinsonian primate model further validated the rodent work. ${ }^{28-30}$

By the 1980 s fetal grafting entered a new era. In addition to PD, grafting was employed in other models like epilepsy, Huntington's disease, Alzheimer's disease, and spinal cord injury. ${ }^{31-36}$ To date, PD has been the first condition in which neural grafting has been clinically applied.

\section{Adrenal Medullary Grafts}

The rationale for the use of adrenal medullary tissue in neural grafting for PD was based primarily on the possibility of using autologous tissue, thereby avoiding the complex ethical and immunological issues surrounding fetal tissue.

The normal adrenal medulla synthesizes dopamine in large amounts as a precursor to adrenaline. Adrenal medullary cells are neural crest-derived cells that produce catecholamines. Catecholamine production by the adrenal medullary cells is under regulation by both neural and endocrine elements. High levels of circulating cortisol from the adrenal cortex stimulates adrenal chromaffin cells to express an endocrine phenotype which includes production of an enzyme phenylethanolamine$\mathrm{N}$-methyl transferase (PNMT) that converts norepinephrine to epinephrine. Removal of these cells from the adrenal gland allows these cells to cease production of PNMT and develop neuritic processes in the presence of neurotrophic factors such as nerve growth factor (NGF) ${ }^{37,38}$

The premise that non-synaptic dopamine production would be helpful for PD made sense, as systemic L-dopa was already a proven treatment. In addition, both dopamine agonists and releasing polymers were successful in improving locomotor deficits in the parkinsonian rodent. ${ }^{39}$

It had already been shown that adrenal medullary grafting into the brain of a parkinsonian rat model improved rotational behaviour. ${ }^{27}$ Although survival of adrenal medullary cells grafted into the striatum was poor, the addition of NGF to the grafts increased survival, fibre outgrowth and dopamine production. ${ }^{40,41}$

Comparison between fetal versus adrenal medullary grafting in the parkinsonian rodent model, however, still demonstrated the superiority of fetal nigral tissue. ${ }^{42}$ Despite this knowledge, clinical trials began using adrenal medullary tissue implants.

The first transplant of adrenal medullary cells into the brain of a parkinsonian patient was carried out in 1982 in Sweden, and reported by Backlund et al. in $1985 .{ }^{43}$ In this first trial, medullary tissue from the patient's own adrenal gland was transplanted to a site deep within the caudate nucleus. While no significant deleterious effects were observed, the motor symptoms of PD were improved only briefly and to a modest degree. In a subsequent study, two patients received unilateral adrenal autografts to the putamen. ${ }^{44}$ The first patient in this study, a 46-yearold male, had longer periods in the "on" state during the first two post-operative months. These improvements subsequently disappeared. The second patient reported only minor improvements in gait and balance that lasted for two months.

The most dramatic effects following autografting of adrenal medullary tissue were claimed by Madrazo et al. (1987). ${ }^{45}$ Two young patients (35 and 39 years old) received autografts into a cavity in the head of the caudate nucleus. The tissue was held in place by miniature staples. The graft was placed so that the tissue was in contact with both the caudate nucleus and cerebrospinal fluid. It was reported that improvements in motor symptoms were seen bilaterally, almost immediately after surgery. Five months after the surgical procedure, one patient was able to walk and eat without help and was taken off all medications. Rigidity and akinesia were absent bilaterally and tremor was greatly improved. This dramatic report from Mexico aroused great interest but unfortunately the authors did not evaluate their patients 
by widely accepted standardized methods. Moreover, by the time their article was written eleven patients had been operated on but only two were described in their article. Of the initial eleven patients, two unfortunately died with no histological evidence of graft survival.

Many groups around the world subsequently attempted adrenal medullary autografting into the striatum of parkinsonian patients but were unsuccessful in duplicating the results of the Mexican group. ${ }^{46-51}$

Overall, only modest improvement could be seen in $30 \%$ of the patients who underwent grafting with adrenal medullary cells. The "on" period seemed to be the most significantly altered outcome parameter. The mechanism of this improvement could not be identified with certainty although it is believed to be a transient humoral effect produced by the release of stored dopamine by the adrenal medullary cells. In addition, even within series that were modestly successful there was a variability between patients. There were no clear predictors that could help identify which patients may receive modest improvement. Currently the clinical application of adrenal medullary grafting in PD has been largely abandoned.

\section{Fetal Nigral Grafts}

The success of fetal nigral grafting in the rodent and primate model of PD led to its clinical application. It is estimated that well over 100 patients with PD have received fetal mesencephalic transplants since $1987^{52-75}$ (Table).

Table: Clinical Trials of Human Fetal Mesencephalic Grafting in Parkinsonian Patients*

\begin{tabular}{|c|c|c|c|c|c|c|c|c|c|c|c|c|c|c|}
\hline \multirow[b]{2}{*}{ Authors } & \multirow{2}{*}{$\begin{array}{l}\text { Number of } \\
\text { Patients }\end{array}$} & \multirow{2}{*}{$\begin{array}{c}\text { Follow-Up } \\
\text { Period } \\
\text { (months) }\end{array}$} & \multirow{2}{*}{$\begin{array}{l}\text { Patient } \\
\text { Age (yrs) }\end{array}$} & \multirow{2}{*}{$\begin{array}{l}\text { Type of } \\
\text { Graft }\end{array}$} & \multirow{2}{*}{$\begin{array}{l}\text { Unilateral/ } \\
\text { Bilateral }\end{array}$} & \multirow{2}{*}{ Site } & \multirow{2}{*}{$\begin{array}{c}\text { NoJAge of } \\
\text { Fetal Cadavers } \\
\text { (wks) }\end{array}$} & \multirow{2}{*}{$\begin{array}{c}\text { Immunosup } \\
\text { pression }\end{array}$} & \multirow{2}{*}{ ip Test } & \multicolumn{3}{|c|}{ Benefit } & \multicolumn{2}{|c|}{$\begin{array}{l}\text { Decrease Graft } \\
\text { Levo-Dopa Survival }\end{array}$} \\
\hline & & & & & & & & & & None & Mild & Mod & Doseage & (PET) \\
\hline Lindvall et al. & 2 & 6 & 48,55 & susp & uni & $\mathrm{C}+\mathrm{P}$ & $3-4 / 8-10$ & Yes & UPDRS & 0 & 2 & 0 & No & + \\
\hline Madrazo et al. & 4 & $19-32$ & 45,52 & solid & uni & $\mathrm{C}$ & $1 / 12-14$ & Yes & $\mathrm{H} \& \mathrm{Y}$ & & & & Yes & \\
\hline $\begin{array}{l}\text { Henderson and } \\
\text { Hitchcock et al. }{ }^{\mathrm{a}}\end{array}$ & 12 & 6,12 & 41,67 & susp & uni & C & $1 / 11-19$ & No & $\begin{array}{l}\text { BPRS, H\&Y } \\
\text { NUDS, WRS } \\
\end{array}$ & 3 & 3 & 3 & Yes & $\mathrm{N} / \mathrm{R}$ \\
\hline Molina et al. & 30 & 24 & $36-55$ & solid & uni & $\mathrm{C}$ & $1 / 6-12$ & Yes & $\begin{array}{l}\text { NUDS } \\
\text { UPDRS, H\&Y }\end{array}$ & & & & Yes & \\
\hline Spencer et al. & 4 & $4-18$ & $47-63$ & solid & uni & $\mathrm{C}$ & $1 / 7-11$ & Yes & $\mathrm{H} \& \mathrm{Y}$ & 1 & 3 & 0 & Yes & ++ \\
\hline Peschanski et al. & 2 & 10,17 & $40-70$ & susp & uni & $\mathrm{C}+\mathrm{P}$ & $2 / 6-8,3 / 6-9$ & Yes $\mathrm{U}$ & $\begin{array}{l}\text { UPDRS, H\&Y } \\
\text { UPDRS, }\end{array}$ & 0 & 0 & 2 & Yes & ++ \\
\hline Widner et al. & 2 & $22-24$ & 53,40 & susp & bilat & $\mathrm{C}+\mathrm{P}$ & $6-8 / 6-8$ & Yes $\mathrm{H}$ & $\begin{array}{l}\text { I\&Y, S\&E, AIMS } \\
\text { UPDRS, S\&E, }\end{array}$ & 0 & 0 & 2 & Yes & ++ \\
\hline Dymecki et al. & 3 & $12-30$ & $48-53$ & solid & uni & $\mathrm{C}$ & $1 / 11-12$ & Yes & $\begin{array}{c}\text { H\&Y } \\
\text { UPDRS, S\&E, }\end{array}$ & 0 & 0 & 3 & No & $N / R$ \\
\hline Freeman et al. & 4 & 6 & $39-61$ & solid & bilat & $\mathbf{P}$ & $6-8 / 6,5-9$ & Yes & $\mathrm{H} \& \mathrm{Y}$ & 0 & 0 & 4 & No & ++ \\
\hline
\end{tabular}

* This table is a compilation of clinical trials of fetal tissue grafting in parkinsonian patients. There are other clinical trials ongoing and a number of patients that have been transplanted in these and other centres that have not been reported here due to the lack of published follow up data.

${ }^{\mathrm{a}}=$ an additional 31 patients have been transplanted and presented in abstract form without long-term follow up data

${ }^{b}=$ an additional 18 patients have been transplanted and presented in abstract form without long -term follow up data

solid = solid graft

uni $=$ unilateral graft susp $=$ cell suspension graft

$\mathrm{C}=$ caudate

bil = bilateral graft

VEP $=$ visual evoked potential

$\mathbf{P}=$ putamen

UPDRS = Unified Parkinson's Disease Rating Scale

S\&E = Schwab-England Activities of Daily Living

H\&Y = Hoehn and Yahr Staging

BPRS = Birmingham Parkinsonian Rating Scale

NUDS $=$ North Western University Disability Scale

AIMS = Abnormal Involuntary Movement Scale

$\mathbf{N} / \mathbf{R}=$ not reported 
Fetal mesencephalic grafting arrived on the heels of the largely dissappointing adrenal medullary autografting trials and seemed to offer great promise from the outset. The first report of fetal grafting was published in 1987 by a Chinese group that utilized fetal VM tissue clinically in a 54-year-old male with parkinsonian features. ${ }^{52}$ They stereotactically transplanted this tissue from a 20 -week-old fetus into a previously created cavity in the head of the caudate nucleus. One year later, both Madrazo and Lindvall reported their experience with grafted fetal VM into patients with PD. ${ }^{53,58}$ The Swedish trials were by far the most informative. In the first Swedish trial, two middle aged patients with advanced PD were grafted with a cell suspension from 8-10 week old fetuses that was implanted into the putamen and caudate stereotactically. ${ }^{54}$ The patients were immunosuppressed with cyclosporine, azathioprine and prednisone. Both patients had some improvement in speed of movement and in motor readiness potentials. Positron emission tomography (PET) scanning showed a slight increase in fluorodopa uptake in the grafted striatum in both patients twelve months after the implantation procedure. Better results were reported by Lindvall et al. in 1990 in a second series of patients in which some technical improvements were introduced such as a thinner implantation cannula and a shorter time interval between the harvesting of tissue and the grafting procedure. ${ }^{55}$ In the first patient from this second series, a significant reduction in rigidity and time spent in the "off" period was observed eight months post-transplant. Furthermore, there was evidence of increased tracer uptake in the striatum in the post operative PET scan.

By 1990, with several experimental neural grafting programs established worldwide, it became apparent at the Fernstrom Symposium on Intracerebral Transplantation in Sweden that a standardized protocol for reporting procedures and results was lacking. This symposium culminated in the formation of the Core Assessment Program for Intracerebral Transplantations (CAPIT) committee which recommended not only uniform criteria for the diagnosis of PD but also standard definitions of "on-off" periods and a minimum clinical assessment battery to include the Unified Parkinson's Disease Rating Scale (UPDRS), Hoehn and Yahr Staging (H\&Y) Scale, Dyskinesia Rating Scale and a Self-reporting diary. ${ }^{76}$ In addition, timed motor testing was suggested pre- and post-operatively. Fetal age reporting, medication changes and imaging guidelines have also been adopted by most investigators in the field that will facilitate comparison of results among the different transplant centres.

In 1992, three important studies were reported in the New England Journal of Medicine ${ }^{67.70 .72}$ Two American groups stereotactically implanted fetal tissue into patients with PD while a Swedish group reported the results of grafting in patients with 1-methyl-4-phenyl-1,2,3,6-tetrahydopyridine (MPTP) induced parkinsonism. Spencer et al. utilized VM fetal tissue collected from fetuses of 7-11 weeks gestational age that was cryopreserved in liquid nitrogen. ${ }^{72}$ Solid fragments of fetal tissue were implanted into the right caudate nucleus of four patients. Cyclosporine was administered for six months postoperatively and no serious adverse effects were observed up to 18 months post-grafting. The results showed bilateral improvement in motor tasks and activities of daily living (ADL) in three patients. In one patient, tracer uptake in the caudate nucleus returned to normal levels as assessed by PET scan.

In the study by Freed et al. five patients received bilateral mesencephalic solid grafts (7-8 weeks gestational age) in the caudate and putamen and two patients received unilateral grafts in the same area. ${ }^{67}$ Every other patient received immunosuppression with cyclosporine and prednisone. All seven patients reported improvement according to the ADL scale and five of the patients had improvement in their neurological exam. At least one of the cases demonstrated bilateral increase in fluorodopa uptake on PET scanning up to 46 months post grafting.

In the third study, Widner et al. reported substantial and sustained improvement in motor function in two patients with MPTP induced parkinsonism. ${ }^{70}$ These patients were grafted bilaterally with cell suspensions of fetal VM tissue (6-8 weeks gestational age). Both patients showed evidence of graft survival as assessed by PET scan.

The best clinical results of fetal dopaminergic transplants in patients with $\mathrm{PD}$, to date, have come from the American group in Tampa, Florida. This group recently reported significant improvements in the UPDRS scores and striatal fluorodopa uptake on PET scans in four patients that received bilateral fetal transplants into the postcommissural putamen. ${ }^{69}$ Furthermore, they have published a unique report describing the results of an autopsy conducted in a patient that died eighteen months after transplantation from causes unrelated to the transplant procedure. ${ }^{73}$ Sections of the graft revealed robust survival of transplanted cells which provided extensive striatal reinnervation in an organotypic pattern to the host putamen. More than 200,000 viable dopaminergic neurons were counted in the graft. Ultrastructural studies revealed synaptic connections between grafted and host neurons and in situ hybridization demonstrated abundant tyrosine hydroxylase mRNA expression. This case demonstrates the capacity of grafted fetal nigral cells to survive and reinnervate the human striatum, strongly suggesting that this is the primary mechanism responsible for the clinical benefits and PET scan changes observed following transplantation.

The relative infancy of fetal transplantation for PD does not allow for much long term data analysis. However, there is evidence of persistent significant improvement in ADL (both in the "on" and "off" state), decreasing drug dosages and Hoehn and Yahr scores that correlated well with increased fluorodopa uptake on PET scans several years after neural transplantation. ${ }^{58,74}$

\section{Grafting ISSUES to BE RESOLVED}

Overall the published results of clinical trials with fetal tissue have demonstrated, so far, some clinical improvement in function. Currently in the United States, two randomized double blind placebo trials funded by the National Institute of Health (NIH) are underway to address the clinical significance of fetal transplantation in PD patients. A clinical trial with fetal cell suspension grafting into selected parkinsonian patients is also underway in Halifax to help address some of the issues discussed in this review. It is clear that in order for neural transplantation to become an accepted therapeutic option for the treatment of PD a number of issues need to be resolved.

\section{Embryonic Donor Age}

Harvesting of fetal tissue should occur when dopaminergic cells first begin to appear in the VM and before there is neuritic outgrowth. The problem with harvesting tissue that has already 
developed neuritic processess is that these processes are easily axotomized which results in neuronal death. Overall, dopamineproducing neurons appear approximately 5.5 weeks after conception in the subventricular zone. ${ }^{77,78}$ By 8 weeks there is neuritic outgrowth; therefore the optimal window for tissue harvest appears to be from 5.5 to 8 weeks of gestational age. The harvesting window of solid tissue may be extended to 9 weeks post-conception because of the decreased likelihood of damaging the neuritic processes within solid chunks of tissue. ${ }^{79}$

The harvest window is of critical importance for the survival of grafted tissue. The difference in harvest times of fetal VM by the groups engaged in clinical trials (Table 1) may have significant implications in the variability in clinical outcomes on parkinsonian patients receiving fetal grafts. There appears now to be a concensus in the optimal time of harvesting VM tissue for transplantation; 6-8 weeks of gestational age for cell suspensions and 6-9 weeks for solid grafts.

\section{Neural Transplantation Technique}

Two transplantation techniques have been used both in animal models and humans. The first technique is a two staged procedure which involves placing a solid graft in a previously created cavity. This cavity, after a few weeks, grows a vessel rich pial cavity that acts as a "culturing bed" for the graft and improves its survival. This technique has worked well in animal models. A modification of this technique has been applied clinically and involves implanting the tissue in a cavity on the ventricular surface of the caudate nucleus; in this way the graft is bathed by cerebrospinal fluid and its nutrients. The cavity and the implant are done at the same time using an open microsurgical procedure..$^{45}$

The second technique involves stereotactic implantation of a cell suspension or small solid pieces of tissue in the caudate, putamen or both without the use of a previously created cavity..$^{55,67,74}$

There are advantages for using both solid and cell suspension techniques in neural grafting. A suspension of cells allows for both quantification and viability assessment of the cells before transplantation. In comparison, solid tissue grafting is technically easier to prepare and there is maintenance of the VM architecture. Solid tissue can be transplanted at a slightly later gestational age allowing for easier pooling of donors. ${ }^{79}$

\section{Graft Survival}

One of the most difficult issues to overcome in neural transplantation is the problem of poor graft survival. Thus far the survival rate of grafted dopaminergic neurons in animal models and possibly in the clinical setting has only been in the range of 5$10 \%{ }^{80.81}$ A number of factors may decrease survival rate, such as obtaining dopaminergic tissue outside the optimal harvesting window (see embryonic donor age). Cell death can occur at the time of harvest (dissection trauma), during the period between the harvesting of tissue and implantation, during preparation of cell suspension or solid tissue for implant, during the surgical procedure (implantation trauma) and after implantation by possible immunological rejection by the host or ischemia due to poor vascular supply to the graft.

A number of strategies are being studied in order to increase cell survival. Trophic factors such as brain-derived neurotrophic factor (BDNF), epidermal growth factor (EGF), glial derived neurotrophic factor (GDNF), platelet derived growth factor
(PFGF), acidic fibroblast growth factor (aFGF) and basic fibroblast growth factor (bFGF) have promoted increased survival of tyrosine hydroxylase neurons in cultures of fetal mesencephalon. ${ }^{82}$ Recent studies involving the transplantation of dopaminergic grafts exposed to these trophic factors have demonstrated both increased survivability and a decrease in apomorphine-induced rotation. ${ }^{83-85}$ GDNF appears to be particularly effective in increasing dopaminergic cell survival. We have recently demonstrated a significant increase in survival of grafted dopaminergic neurons exposed to GDNF during a hibernation period when compared with control grafts not exposed to GDNF. ${ }^{86}$ This finding has important implications in clinical transplantation because it promotes neuronal protection of cells while bacteriological and virological tests are conducted prior to the implantation procedure to ensure that the grafted tissue does not contain any infectious agents.

Other compounds such as lazaroids (Triliazad) have also been shown to be helpful in increasing cell survival (theoretically by limiting lipid peroxidation) within dopaminergic grafts. Triliazad has been shown to increase the cell survivability $(2.4$ times) of mixed human and rat VM cells that have been placed in culture. ${ }^{87,88}$

Decreased implantation trauma has been achieved by the use of a micrografting procedure in which the implantation cannula diameter has been reduced significantly and the preparation of the cell suspension has been optimized. ${ }^{89}$ The use of neurotrophic factors in combination with microtransplantation may in the future increase graft survival and maximize the clinical benefits of dopaminergic grafts in the parkinsonian patient.

\section{Transplant Placement}

To date, the main transplant strategy has been to place nigral grafts not in their ontogenic site (substantia nigra) but into their target area (striatum). The main reason for this ectopic placement is the apparent inability of nigral grafts placed in the VM to grow axons over long distances that are capable of reaching their striatal target. This failure may be the result of inhibitory factors in the myelinated pathway or partly due to a lack of guidance by the host. ${ }^{90-92}$ As a result the cells are placed in the striatum, the site of the dopaminergic terminals. Placement of the cells within the striatum is also a matter of debate. The putamen appears to be a logical choice as stimulation studies on the rhesus monkey have shown that the putamen is more directly involved in motor behaviour than the caudate. ${ }^{93}$ Human autopsy and PET studies have shown that the depletion of dopamine is greatest in the posterior putamen. ${ }^{94,95}$ So far, a concensus for the optimal placement of grafts has not been reached and this has contributed to the difficulty in comparing results of the different clinical trials (Table 1).

Restoration of dopaminergic innervation to both the substantia nigra and striatum may be important as demonstrated in a study of simultaneous intrastriatal and intranigral dopaminergic transplant in the parkinsonian rat model.${ }^{96}$ In this study, reconstruction of the nigrostriatal pathway was achieved 6 weeks after grafting and was accompanied by a faster and more complete functional recovery in the lesioned host.

\section{Immunosuppression}

Many current clinical trials are using limited short term immunosuppression when grafting fetal tissue. This issue is controversial as clinical groups have varied in their usage of 
immunosuppression (Table 1). Overall, there have been some poor results in series both with and without immunosuppression ${ }^{65,67}$ One must weigh the real risks of immunosuppressives (infections, hepatotoxicity, nephrotoxicity, bone marrow suppression) with the theoretical benefits they may offer. However, xenografting with human fetal cells into the rodent brain has been clearly shown to require immunosuppression. ${ }^{97}$ The central nervous system has always been thought to be an immunoprivileged site but there is a chance that the surgical procedure may disrupt the blood-brain barrier. Disruption of this barrier may allow the transplant to stimulate the immune system. It has been demonstrated that fetal brain tissue lacks the major histocompatibility complex (MHC) surface markers, making it harder for the immune system to target it; however, a mononuclear cellular reaction still does occur in response to transplant procedures. ${ }^{98-}$ ${ }^{100}$ Despite all this controversy the only evidence of robust graft survival has been seen in a patient that received short term (six months) immunosuppression. ${ }^{73}$ This patient expired twelve months after completing his immunosuppression and when the graft was examined there was no evidence of rejection. Hopefully the role of immunosuppression in neural transplantation may be clarified by the two NIH-funded trials currently in progress in the United States in which one group uses short term immunosuppression while the other group does not.

\section{Transplant Regulation}

Although ectopically placed embryonic grafts in the striatum extend axons and form synapses in the host striatum to restore efferent nigrostriatal input, reciprocal host afferent striatonigral input appears to be lacking. ${ }^{101-104}$ Furthermore, ectopically placed grafts fail to reestablish dendritic dopaminergic control to the substantia nigra (pars reticulata) which is important in the regulation of basal ganglia outflow. ${ }^{105}$ The lack of host-graft connectivity and dendritic release of dopamine are likely contributors in limiting complete symptomatic recovery in transplant recipients. Many groups have demonstrated the restoration of efferent nigrostriatal connections with the ectopic placement of nigral grafts, however, the lack of afferent input into the graft has only recently been addressed ${ }^{96}$ Kondoh et al. demonstrated that grafted dopaminergic neurons will increase striatal dopamine release in response to an enhanced level of glutamate. ${ }^{106}$ These results suggested that host glutamatergic pathways may modulate grafted dopaminergic neurons.

Our laboratory has recently demonstrated the ability to increase striatal reinnervation and reconstitute the nigrostriatal pathway by simultaneously grafting fetal VM cells into the striatum and substantia nigra of 6 -OHDA lesioned rats. ${ }^{96}$ The dopaminergic reinnervation to the striatum and substantia nigra was accompanied by extensive functional effects in the transplanted animals, suggesting that reconstruction of the nigrostriatal pathway may also lead to the reestablishment of some of the nigrostriatal control mechanisms found in the intact system which cannot be recreated by ectopically placed transplants. Clearly, more work is needed to answer the issue of graft control and regulation, which is one of the most serious obstacles that has plagued experimental and clinical neural transplantation.

\section{Alternative Sources of Tissue}

The use of fetal cells for neural transplantation has been crucial for the development of transplantation technology in the central nervous system. Although fetal cells are, at present, the gold standard by which any other type of cells are compared, fetal cells have a number of disadvantages which include; limited supply for the potential demand if this therapy is to be used as a routine therapeutic procedure for the treatment of $P D$, the potential for infection transmission from donors to recipients and the ethical issues related to abortion.

It is clear that fetal cells are only a stage in the continuing development of neural transplantation for PD. A great deal of effort is currently devoted to finding alternative sources of tissue for transplantation and significant advances have already been made.

The ideal cells to transplant would be those that are abundant, inexpensive, safe, and have the ability to integrate into the host and restore the nigrostriatal circuitry and dopamine levels. Xenografts offer great promise of fulfilling these qualities as ideal donor cells. Fetal cells from the mouse, rabbit, pig, and human have been successfully transplanted into the immunosupressed rodent. ${ }^{97.107-110}$ Fetal pig mesencephalic tissue has been transplanted into the parkinsonian rodent model with success in normalizing rotational behaviour. This animal has some theoretical advantages as a donor cell source as the developmental course of the pig parallels the human and these cells have the possible ability to reinnervate large target areas. ${ }^{109}$

Genetically engineered cells to overexpress tyrosine hydroxylase activity have also shown promise in animal models. ${ }^{1 \prime \prime}$ Recently genetically immortalized nigral cells with increased tyrosine hydroxylase activity were transplanted into the rodent and primate parkinsonian model. Both groups in this small study demonstrated cell survival and improved rotational behaviour." Neuroepithelial stem cells capable of differentiating into both neurons and astrocytes under the influence of the mitogen epidermal growth factor are also promising. ${ }^{112}$

It is clear that non-fetal sources of tissue will be available in the future for clinical neural transplantation. However, clinical research using fetal cells is of crucial importance at present for the continuing development and refinement of the neural transplantation technology which may use non-fetal tissue for the treatment of PD and possible other devastating conditions such as Huntington's disease and spinal cord injury in the future.

\section{Other Neurosurgical Procedures}

Functional neurosurgery in PD has progressed greatly due to technological advancements and a better understanding of the physiology within the basal ganglia. Currently the most frequently targeted areas are the thalamus, pallidum and subthalamic nucleus. However, controversy still surrounds the ideal target to lesion as well as the best suited patient for these procedures.

Thalamotomy has been employed in PD for many years and involves placing a lesion either within the ventrolateral (VL) or into the ventralis intermedius (VIM) nucleus of the thalamus. Tasker prospectively reviewed 75 patients who underwent VIM thalamotomy and demonstrated major improvement in contralateral tremor in the hand and fingers in $82 \%$ of his patients. ${ }^{113}$ Other more recent studies have also shown the effectiveness of thalamotomy for relief of parkinsonian tremor. ${ }^{114-117}$ Long-term follow up suggests that at ten years after unilateral thalamotomy there is still improvement in $40 \%$ to $60 \%$ of the patients. ${ }^{117}$ The morbidity and mortality of unilateral thalamotomy today makes 
it a relatively safe procedure for the control of unilateral tremor. However, bilateral thalamotomy is still controversial as a significant proportion of patients receiving bilateral lesions may suffer from memory, cognitive and speech disorders. These complications attributed to the lesions have led to the development of thalamic stimulation techniques.

Thalamic stimulation has the benefit of not only being reversible but also gives the physician the ability to tailor the frequency for each individual patient in order to maximize the benefit. Benabid et al. have recently implanted thalamic stimulating electrodes unilaterally and bilaterally into the VIM of 61 parkinsonian patients with impressive results. ${ }^{118}$

Pioneering work by Delong and colleagues has increased our understanding of basal ganglia circuitry in PD. ${ }^{119,120}$ The circuitry of the basal ganglia is altered substantially after the loss of dopaminergic nigral neurons and striatal dopamine. In the pathological state the external pallidal segment (GPe) and susthalamic nucleus (STN) turn on the internal pallidal segment (GPi) so it can further inhibit the anterior aspect of the ventrolateral thalamus. Work with the primate model exposed to MPTP has shown an increase of firing within the STN, which is responsible for driving the GPi's inhibition of the thalamus and the relative resultant turning "off" of the cortex.

Laitinen et al. (1992) has duplicated the previous results of Svennilson et al. (1960) utilizing the posteroventral pallidotomy described by Leksell. ${ }^{121.122}$ Laitinen studied 38 patients with medically intractable PD, who were subjected to a posteroventral pallidotomy. The bulk of these patients had pure bradykinesia with and without tremor. Mean follow up at 28 weeks demonstrated greater than $80 \%$ improvement of bradykinesia, rigidity and tremor. In addition a recent report by CeballosBauman et al. ${ }^{123}$ illustrated using PET scanning the ability of both the supplementary motor area and the dorsolateral prefrontal cortex to become activated following a posteroventral pallidotomy. A recent Canadian study has also demonstrated short term benefits with lesioning of globus pallidus internus in fourteen parkinsonian patients. ${ }^{124}$

Although the initial results of unilateral pallidotomy are promising, long term effectiveness has yet to be evaluated. A number of important issues still need to be resolved before this procedure can be applied to the parkinsonian population routinely. The mechanism by which pallidotomy produces its effects, the safety of bilateral lesions and the precise target within the GPi are still poorly understood.

Although subthalamic stimulation is in its infancy, positive results have already been reported. A French group has placed stimulating electrodes into the subthalamic nucleus of eleven parkinsonian patients and reported significant motor improvement. ${ }^{25}$ This improvement included not only an improvement of tremor but also akinesia and rigidity. Stimulation of basal ganglia structures will continue to evolve and may be a promising avenue for the future in the neurosurgical management of parkinsonian patients.

\section{CONCluding Remarks}

It is clear that a number of neurosurgical procedures may be available to the parkinsonian patient in the future. The challenge, at present, is to define which patients may benefit from a specific procedure. The different procedures may not be mutu- ally exclusive and may complement each other. Although neural transplantation may be effective in all symptoms of PD by restoring dopamine and reestablishing the nigrostriatal circuitry, patients in which only one symptom, such as tremor, is predominant may benefit from thalamic stimulation alone. As our understanding of basal ganglia function evolves and the effectiveness of the different surgical procedures is evaluated by long term results, our ability to choose the appropriate procedure for a particular patient will increase.

At present, clinical neural transplantation is at its early stages of development. Many modifications of the transplantation technique are being studied in order to maximize clinical efficacy. At this time fetal transplantation should only be offered as an experimental procedure within a clinical trial setting at a recognized transplantation centre. Current trials are underway in Canada, the United States and Europe that will help define the role of neural transplantation in the treatment of Parkinson's disease.

\section{REFERENCES}

1. Barbeau A, Mars H, Gillo-Joffroy L, et al. A proposed classification of dopa-induced dyskinesia. In: Barbeau A, Macdowell FH, eds. L-Dopa and Parkinsonism. Philadelphia: Davis, 1970: 118-123.

2. Rajput AH, Stern W, Laverly WH. Chronic low dose levodopa therapy in Parkinson's disease: an argument for delaying levodopa therapy. Neurology 1984; 34: $991-997$.

3. Freed WJ, Hoffer BJ, Olson, et al. Transplantation of catecholamine-containing tissues to restore the functional capacity of the damaged nigrostriatal system. In: Sladek JR Jr, Gash DM, eds. Neural Transplants. Development and Function. New York: Plenum Press, 1984: 737-402.

4. Sladek JR Jr, Gash DM. Review article. Nerve-cell grafting in Parkinson's disease. J Neurosurg 1988; 68: 337-351.

5. Fisher LJ, Gage FH. Intracerebral transplantation: basic and clinical applications to the neostriatum. FASEB 1994; 8: 489-496.

6. Hitchcock ER. Current trends in neural transplantation. Neurol Res 1995; 17: 33-37.

7. Lindvall O. Neural Transplantation. Cell Transplantation 1995; 4: $391-400$

8. Olanow CW, Kordower JH, Freeman TB. Fetal nigral transplantation as a therapy for Parkinson's disease. Trends Neurosci 1996; 19: $102-109$.

9. Freed WJ. Intracerebral adrenal medulla grafts: a review. Exp Neurol 1990; 110: 139-166.

10. Thompson WG. Successful brain grafting. NY Med J 1890; 51 : 701.

11. Saltykow S. Versuche uber Gehirn replantation, Zugleich ein Beitrag zur Kenntniss reactiver Vorgange an den zelligen Gehirneelementen. Arch Psychiatr Nervenkr 1905; 40: 329-388.

12. Dunn E. Primary and secondary findings in a series of attempts to transplant cerebral cortex in albino rats. J Comp Neurol 1917; 22: 565-582.

13. Legros Clark WE. Neuronal differentiation in implanted foetal cortical tissue. J Neurol Psychiatry 1940; 3: 263-284.

14. May RM. Connexions entre des cellules cerebrales et des muscles de la cause dans leur greffe blephoplastique intraoculaire simultanee chez la souris. Anat Microsc Morphol Exp 1949; 38: 145.

15. Flenko B, Szentagothai J. Oestrogen sensitive nervous structures in the hypothalamus. Acta Endocrinol 1957; 26: 121-127.

16. Halasz B, Pupp L, Uhlarik S, et al. Growth of hypophysectomized rats bearing pituitary transplant in the hypothalamus. Acta Physiol Hung 1963; 23: 287-292.

17. Halasz B, Pupp L, Uhlarik S, et al. Further studies on the hormone secretion of the anterior pituitary transplanted into the hypophysiotrophic areas of the rat hypothalamus. Endocrinology 1965; 77: 343-355.

18. Das GD. Transplantation of embryonic neural tissue in the mammalian brain. Growth and differentiation of neuroblasts from various regions of the embryonic brain in the cerebellum of 
neonate rats. J Life Sci 1974; 4: 93-124.

19. Lund R, Hauscha $S$. Transplanted neural tissue develops connections with host rat brain. Science 1976; 193: 582-584.

20. Bjorklund A, Kramer LF, Stenevi U. Cholinergic reinervation of rat hippocampus by septal implants is stimulated by perforant path lesion. Brain Res 1979; 173: 57-64.

21. Bjorklund A, Stenevi U. Reconstruction of the nigrostriatal dopamine pathway by intracerebral nigral transplants. Brain Res 1979; 177: 555-560.

22. Bjorklund A, Stenevi U. Reformation of the severed septohippocampal cholinergic pathway in the adult rat by transplanted septal neurons. Cell Tissue Res 1977; 185: 289-302.

23. Bjorklund A, Stenevi U, Svendgaard NA. Growth of transplanted monoaminergic neurones into the adult hippocampus along the perforant path. Nature 1976; 262: 787-790.

24. Bjorklund A, Dunnett SB, Stenevi U, et al. Reinnervation of the denervated striatum by substantia nigra transplants. Functional consequences as revealed by pharmacological and sensorimotor testing. Brain Res 1980; 199: 307-333.

25. Perlow MJ, Freed WJ, Hoffer BJ, et al. Brain grafts reduce motor abnormalities produced by destruction of nigro-striatal dopamine system. Science 1979; 204: 643-647.

26. Freed WJ, Perlow MJ, Karoum F, et al. Restoration of dopaminergic function by grafting of fetal rat substantia nigra to the caudate nucleus: long-term behavioural, biochemical, and histochemical studies. Ann Neurol 1980; 8: 510-519.

27. Freed WJ, Morihisa JM, Spoor E, et al. Transplanted adrenal chromaffin cells in rat brain reduce lesion induced rotational behaviour. Nature 1981; 292: 351-352.

28. Redmond DE Jr, Sladek JR Jr, Roth RH, et al. Fetal neuronal grafts in monkeys given methylphenyltetrahydropyridine. Lancet 1986; 1: 1125-1127.

29. Sladek JR Jr, Redmond DE Jr, Collier TJ, et al. Fetal dopamine neural grafts: extended reversal of methylphenyltetrahydropyridine-induced parkinsonism in monkeys. Prog Brain Res 1988; 78: 497-506.

30. Sladek JR Jr, Collier TJ, Haber SN, et al. Survival and growth of fetal catecholamine neurons transplanted into primate brain. Brain Res Bull 1986; 17: 809-818.

31. Stevens JR, Phillips I, Freed WJ, Poltorak M. Cerebral transplants for seizures: preliminary results. Epilepsia 1988; 29: 731-737.

32. Holmes GL, Thompson JL, Huh K, Stuart JD, Carl GF. Effects of neural transplantation on seizures in the immature genetically epilepsy prone rat. Exp Neurol 1992; 116: 52-63.

33. Deckel AW, Robinson RG, Coyle JT, Sanberg PR. Reversal of longterm locomotor abnormalities in the kainic acid model of Huntington's disease by day 18 fetal striatal implants. Eur J Pharmacol 1983; 93: 287-288.

34. Fine A, Dunnett SB, Bjorklund A, Iversen SD. Cholinergic ventral forebrain grafts into the neocortex improve passive avoidance memory in a rat model of Alzheimer's disease. Proc Natl Acad Sci USA 1985; 82: 5227-5230.

35. Bregman BS. Spinal cord transplants permit the growth of serotonergic axons across the site of neonatal spinal cord transection. Dev Brain Res 1987; 34: 265-279.

36. Das GD. Neural transplantation in the spinal cord of adult rats. $\mathbf{J}$ Neurol Sci 1983; 62: 191-210.

37. Wurtman RJ, Pohorecky LA, Baliga BS. Adrenocortical control of the biosynthesis of epinephrine and proteins in the adrenal medulla. Pharmacol Rev 1972; 24: 411-426.

38. Unsicker K, Rieffert B, Ziegler W. Effects of cell culture conditions, nerve growth factor, dexamethasone and cyclic AMP on adrenal chromaffin cells in vitro. Adv Biochem Pharmacol 1980; 25: $51-59$.

39. Winn SR, Wahlberg L, Tresro PA, et al. An encapsulated dopamine-releasing polymer alleviates experimental Parkinsonian in rats. Exp Neurol 1989; 105: 244-250.

40. Stromberg I, Herrera-Marschitz M, Hultgren L, et al. Adrenal medullary implants in the dopamine denervated rat striatum. 1 . Acute catecholamine levels in grafts and host caudate as determined by HPLC-electrochemistry and fluorescence histochemical image analysis. Brain Res 1984; 297: 41-51.
41. Stromberg I, Herrera-Marschitz M, Ungerstedt U, et al. Chronic implants of chromaffin tissue into the dopamine-denervated striatum. Effects of NGF on graft survival, fibre growth and rotational behaviour. Exp Brain Res 1985; 60: 335-349.

42. Brown VJ, Dunnett SB. Comparison of adrenal and foetal nigral grafts on drug-induced rotation in rats with 6-OHDA lesions. Exp Brain Res 1989; 78: 214-218.

43. Backlund EO, Granberg PO, Hamberger B, et al. Transplantation of adrenal medullary tissue to striatum in parkinsonism. First clinical trials. J Neurosurg 1985; 62: 169-173.

44. Lindvall O, Backlund EO, Farde L, et al. Transplantation in Parkinson's disease: two cases of adrenal medullary grafts to putamen. Ann Neurol 1987; 22: 457-468.

45. Madrazo I, Drucker-Colin R, Diaz V, et al. Open microsurgical autograft of adrenal medulla to the right caudate nucleus in Parkinson's disease: a report of two cases. N Engl J Med 1987; 316: 831-834.

46. Allen GS, Burns RS, Tulipan NB, et al. Adrenal medullary transplantation to the caudate nucleus in Parkinsons disease. Initial results in 18 patients. Arch Neurol 1989; 46: 487-491.

47. Bakay RAE. Preliminary report on adrenal medullary grafting from the American Association of Neurological Surgeons GRAFT project. Restorative Neurol Neurosci 1989; 1: 158.

48. Flores EG. Is autologous transplant of adrenal medulla into the striatum an effective therapy for Parkinson's disease? Restorative Neurol Neurosci 1990; 1: 182.

49. Kelly PJ, Ahlskog JE, Van Heerden JA, et al. Adrenal medullary autograft transplantation into the striatum of Parkinson's disease. Mayo Clin Proc 1989; 64: 282-290.

50. Goetz CG, Stebbins GT, Klawans, et al. United Parkinson Foundation Neural Transplantation Registry (1991) United Parkinson Foundation Neurotransplantation Registry on adrenal medullary transplants: presurgical, and 1 and 2 year follow-up. Neurology 1991; 41: 1719-1722.

51. Apuzzo MLJ, Neal JH, Waters $\mathrm{CH}$, et al. Utilization of unilateral and bilateral sterotactically placed adrenomedullary-striatal autografts in parkinsonian humans: rationale, techniques, and observations 1990; 26: 746-757.

52. Jiang N, Jiang C, Tang Z, et al. Human foetal brain transplant trials in the treatment of Parkinsonism. Acta Acad Medicin Shangai $1987 ; 14(1): 77$

53. Lindvall O, Rehncrona S, Gustavii B, et al. Fetal dopamine-rich mesencephalic grafts in Parkinson's disease. Lancet 1988; 2: 1483-1484.

54. Lindvall O, Rehncrona S, Brundin P, et al. Human fetal dopamine neurons grafted into the striatum in two patients with severe Parkinson's disease: a detailed account of methodology and a 6month follow-up. Arch Neurol 1989; 46: 615-631.

55. Lindvall $\mathrm{O}$, Brundin $\mathrm{P}$, Widner $\mathrm{H}$, et al. Grafts of fetal dopamine neurons survive and improve motor function in Parkinson's disease. Science 1990; 247: 547.

56. Lindvall $\mathrm{O}$, Widner $\mathrm{H}$, Rehncrona $\mathrm{S}$, et al. Transplantation of fetal dopamine neurons in Parkinson's disease: one year clinical and neurophysiological observations in two patients with putaminal implants. Ann Neurol 1992; 31: 155-165.

57. Lindvall O, Sawle G, Widner $\mathrm{H}$, et al. Evidence for long-term survival and function of dopaminergic grafts in progressive Parkinson's disease. Ann Neurol 1994; 35: 172-180.

58. Madrazo I, Leon V, Torres C, et al. Transplantation of fetal substantia nigra and adrenal medulla to the caudate nucleus in two patients with Parkinson's disease. N Engl J Med 1988; 318: 51.

59. Madrazo I, Franco-Bourland R, Ostrosky-Solis F, et al. Fetal homotransplants (ventral mesencephalon and adrenal tissue) to the striatum of parkinsonian patients. Arch Neurol 1990; 47: 1281-1285.

60. Madrazo I, Franco-Bourland R, Aguilera M, et al. Fetal ventral mesencephalon brain homotransplantation in Parkinson's disease: the Mexican experience. In: Lindvall O, Bjorklund A, Widner $\mathrm{H}$, eds. Intracerebral Transplantation in Movement Disorders. Restorative Neurology, Vol 4, Amsterdam: Elsevier, 1991: 123-129. 
61. Madrazo I, Franco-Bourland R, Ostrosky-Solis F, et al. Neural transplantation (auto-adrenal, fetal nigral and fetal adrenal) in Parkinsons disease. The Mexican experience. Prog Brain Res $1990 \mathrm{~b} ; 82: 593-602$.

62. Molina H, Quinones R, Alvarez L, et al. Transplantation of human fetal mesencephalic tissue in caudate nucleus as treatment for Parkinson's disease: the Cuban experience. In: Lindvall O, Bjorklund A, Widner $\mathrm{H}$. eds. Intracerebral Transplantation in Movement Disorders. Restorative Neurology, Vol. 4, Amsterdam: Elsevier, 1991: 99-110.

63. Hitchcock ER, Clough C, Hughes R, Kenny B. Embryos and Parkinson's disease. Lancet 1988; 1: 1274.

64. Hitchcock ER, Kenny BG, Clough CG, et al. Stereotactic implantation of foetal mesencephalon (STIM): the UK experience. In: Dunnett SB, Richards S-J, eds. Neural Transplantation: From Molecular Basis to Clinical Applications. Progress in Brain Research. Amsterdam: Elsevier, 1990: 723-728.

65. Henderson BTH, Clough CG, Hughes RC, Hitchcock ER, Kenny BG. Implantation of human fetal ventral mesencephalon to the right caudate nucleus in advanced Parkinson's disease. Arch Neurol 1991; 48: 822-827.

66. Freed CR, Breeze RE, Rosenberg NL, et al. Transplantation of human fetal dopamine cells for Parkinson's disease: results at 1 year. Arch Neurol 1990; 47: 505-512.

67. Freed CR, Breeze RE, Rosenberg NL, et al. Survival of implanted fetal dopamine cells and neurologic improvement 12 to 46 months after transplantation for Parkinson's disease. N Engl J Med 1992; 327: 1549-1555.

68. Lopez-Lozano JJ, Bravo G, Brera B, et al. Long-term follow-up in 10 Parkinson's disease patients subjected to fetal brain grafting into a cavity in the caudate nucleus: the clinica Puerta de Hierro experience. Transplant Pro 1995; 27; 1: 1395-1400.

69. Freeman TB, Olanow CW, Hauser, RA et al. Bilateral fetal nigral transplantation into the postcommissural putamen in Parkinson's disease. Ann Neurol 1995; 38(3): 379-388.

70. Widner H, Tetrud J, Rehncrona S, et al. Bilateral fetal mesencephalic grafting in two patients with Parkinsonism induced by 1-methyl-4-phenyl-1,2,3,6-tetrahydropyridine (MPTP). N Engl J Med 1992; 327: 1556-1563.

71. Peschanski M, Defer G, Guyen JP, et al. Bilateral motor improvement and alteration of L-dopa effect in two patients with Parkinson's disease following intrastriatal transplantation of foetal ventral mesencephalon. Brain 1994; 117: 487-499.

72. Spencer DD, Robbins RJ, Naftolin F, et al. Unilateral transplantation of human fetal mesencephalic tissue into the caudate nucleus of patients with Parkinson's disease. N Engl J Med 1992; 327: 1541-1548.

73. Kordower JH, Freeman TB, Snow BJ, et al. Neuropathological evidence of graft survival and striatal reinnervation after the transplantation of fetal mesencephalic tissue in a patient with Parkinson's disease. N Engl J Med 1995; 332: 1118-1124.

74. Freed CR, Breeze RE, Leehey MA, et al. Eight years experience with fetal neurotransplantation in patients with advanced Parkinson's disease. Soc Neurosci Abst 1996; 22(2): 481.3

75. Wu CY, De Zhou M, Bao X-F, et al. The combined method of transplantation of foetal substantia nigra and stereotactic thalamotomy for Parkinson's disease. Br J Neurosurg 1994; 8: 709-716.

76. Langston JW, Widner H, Goetz CG, et al. Core assessment program for intracerebral transplantation (CAPIT). Mov Disord 1992; 7: 2-13.

77. Freeman TB, Spence MS, Boss BD, et al. Development of dopaminergic neurons in the human substantia nigra. Exp Neurol 1991; 113: 344-353.

78. Verney C, Zecevic N, Nikolic B, et al. Early evidence of catecholaminergic cell groups in 5 and 6 week old human embryos using tyrosine hydroxylase and dopamine-B-hydroxylase immunocytochemistry. Neurosci Lett 1991; 131: 121-124.

79. Freeman TB, Sanberg PR, Navelt GM, et al. Influence of donor age on the survival of solid and suspension intraparenchymal human embryonic micrografts. Cell Transplant 1995; 4: 141-145.

80. German DC, Schlosselberg DS, Woodward DJ. Three dimensional computer reconstruction of midbrain dopaminergic neuronal population from mouse to man. J Neural Transm 1983; 57: 243-254.
81. Brundin P, Strecker RE, Widner H, et al. Human fetal dopamine neurons grafted in a rat model of Parkinson's disease: immunological aspects, spontaneous and drug induced behaviour, and dopamine release. Exp Brain Res 1988; 70: 192-208.

82. Gash DM, Bresjanac M, Junn F, et al. Trophic mechanisms mediating functional recovery following intrastriatal implantation. In: Dunnett SB, Bjorklund A, eds. Functional Neural Transplantation. New York: Raven Press, 1994: 140.

83. Yurek DM, Lu W, Hipkens S, Wiegand SJ. BDNF enhances the functional reinnervation of the striatum by grafted fetal dopamine neurons. Exp Neurol 1996; 137: 105-118.

84. Mott JL, Eken S, Bowenkamp K, et al. Effects of glial cell linederived neurotrophic factor on dopaminergic transplants to the 6OHDA denervated striatum. Soc Neurosci Abst 1996; 22(2): 592.10.

85. Zastrow DJ, Zawada WM, Clarkson, et al. Preincubation with growth factors improves survival of early mesencephalic grafts in hemiparkinsonian rats. Soc Neurosci Abst 1996; 22(2): 592.17

86. Sanford E, Hong M, Poirier R, Guido M, Mendez I. Effect of the neurotrophic factor GDNF on transplanted dopaminergic cells treated acutely at the time of transplantation and during hibernation. Soc Neurosci Abst 1996; 22(3): 767.12.

87. Nakao N, Frodl EM, Duan WM, Widner H, Brundin P. Lazoroids improve the survival of grafted rat embryonic dopamine neurons. Proc Natl Acad Sci USA 1994; 91: 12408-12414.

88. Othberg A, Keep M, Brundin P, Lindvall O. Tirilazad mesylate increases survival of embryonic dopaminergic neurons in vitro. Soc Neurosci Abst 1996; 22(2): 592.12.

89. Nikkhah G, Cunningham MG, Jodicke A, Knappe U, Bjorklund A. Improved graft survival and striatal reinnervation by microtransplantation of fetal nigral cell suspensions in the rat Parkinson's model. Brain Res 1994: 633; 133-143.

90. Schnell L, Schwab ME. Axonal regeneration in the rat spinal cord produced an antibody against myelin-associated growth inhibitors. Nature 1990; 343: 269-272.

91. Schwab ME. Myelin-associated inhibitors of neurite growth and regeneration in the CNS. Trends Neurosci 1990; 13:452-455.

92. Schwab ME, Kapfhammer JP, Bandtlow CE. Inhibitors of neurite growth. Ann Rev Neurosci 1993; 16: 565-595.

93. Alexander GE, Delong MR. Microstimulation of the primate neostriatum. II. Somatotopic organization of striatal microexcitable zones and their relation to neuronal response properties. J Neurophysiol 1985; 53: 1417-1430.

94. Kish SJ, Shannak K, Hornykiewicz O. Uneven pattern of dopamine loss in the striatum of patients with idiopathic Parkinson's disease. Pathophysiologic and clinical implications. N Engl J Med 1988; 318: 876-880.

95. Brooks DJ, Ibanez V, Sawle GV, et al. Differing patterns of striatal ${ }^{18}$ F-dopa uptake in Parkinson's disease, multiple system atrophy, and progressive supranuclear palsy. Ann Neurol 1990; 28: 547555.

96. Mendez I, Sadi D, Hong M. Reconstruction of the nigrostriatal pathway by simultaneous intrastriatal and intranigral dopaminergic transplants. J Neurosci 1996; 16(22): 7216-7227.

97. Brundin P, Strecker RE, Widner H, et al. Human fetal dopaminergic neurons grafted in a rat model of Parkinson's disease: immunological aspects, spontaneous and drug-induced behaviour, and dopamine release. Exp Brain Res 1988; 70: 192-208.

98. Widner $\mathrm{H}$, Brundin $\mathrm{P}$, Bjorklund $\mathrm{A}$, et al. Survival and immunogenicity of dissociated allogenic fetal neural dopamine rich grafts when implanted in the brains of adult mice. Exp Brain Res 1989; 76: 187-197.

99. Grabowska A, Lampson LA. Expression of class I and II major histocompatibility (MHC) antigens in the developing CNS. J Neural Transpla Plast 1992; 3: 204-205.

100. Boyer KL, Ansani A, Chan WC, et al. Immunological response to injury and grafting in the central nervous system. J Neural Transpla Plast 1992; 3: 202-203.

101. Freund TF, Bolam JP, Bjorklund A, et al. Efferent synaptic connections of grafted dopaminergic neurons reinnervating the host neostriatum: a tyrosine hydroxylase immunocytochemical study. J Neurosci 1985; 5: 603-616. 
102. Clarke DJ, Brundin P, Strecker RE, et al. Human fetal dopamine neurons grafted in a rat model of Parkinson's disease: ultrastructural evidence for synapse formation using tyrosine hydroxylase immunocytochemistry. Exp Brain Res 1988; 73: 115-126.

103. Mendez I, Elisevich K, Flumerfelt B. Dopaminergic innervation of substance P-containing striatal neurons by fetal nigral grafts: an ultrastructural double-labeling immunocytochemical study. J Comp Neurol 1991; 308: 66-78.

104. Doucet G, Murata Y, Brundin P, et al. Host afferents into intrastriatal transplants of fetal ventral mesencephalon. Exp Neurol 1989; 106: 1-19.

105. Robertson HA. Synergistic interactions of D1- and D2-selective dopamine agonists in animal models for Parkinson's disease: sites of action and implications for the pathogenesis of dyskinesias. Can J Neurol Sci 1992; 19: 147-152.

106. Kondoh T, Lae WC. Glutamate uptake blockade induces striatal dopamine release in 6-Hydroxydopamine rats with intrastriatal grafts: evidence for host modulation of transplanted dopamine neurons. Exp Neurol 1994; 127: 191-198.

107. Bjorklund A, Stenevi U, Dunnett SB, Gage FH. Cross-species neural grafting in a rat model of Parkinson's disease. Nature 1982; 298: 652-654.

108. Freeman TB, Brandeis L, Pearson J, Flamm ES. Cross species grafts of embryonic rabbit mesencephalic tissue survive and cause behavioural recovery in the presence of chronic immunosuppression. In: Azmitia EC, Bjorklund A, eds. Cell and Tissue Transplantation into the Adult Brain. Ann NY Acad Sci, 1987: 699-702.

109. Huffaker TK, Boss BD, Morgan NT, et al. Xenografting of fetal pig ventral mesencephalon corrects motor asymmetry in the rat model of Parkinson's disease. Exp Brain Res 1989; 77: 329-336.

110. Stromberg I, Adams C, Bygdeman M, et al. Long-term effects of human to rat mesencephalic xenografts on rotational behaviour, striatal dopamine receptor binding and mRNA levels. Brain Res Bull 1995; 38: 221-233.

111. Anton R, Kordower JH, Maidment NT, et al. Neural-targeted gene therapy for rodent and primate hemiparkinsonism. Exp Neurol 1994; 127: 207-218.

112. Reynolds BA, Weiss S. Generation of neurons and astrocytes from isolated cells of the adult mammalian central nervous system. Science 1992; 255: 1707-1710.
113. Tasker RR, Siqueira J, Hawrylyshyn P, et al. What happened to VIM thalmotomy for Parkinson's disease? Appl Neurophysiol 1983; 46: 68-83

114. Fox MW, Ahlskog JE, Kelly PJ. Stereotactic ventrolateralis thalamotomy for medically refractable tremor in post-levodopa era of Parkinson's disease patients. J Neurosurg 1991; 75: 723-730.

115. Jankovic J, Candoso F, Grossman R, et al. Outcome after stereotactic thalamotomy for Parkinsonian, essential, and other types of tremor. Neurosurgery 1995; 37: 680-687.

116. Matsumoto K. Reappraisal of ventrolateral thalamotomy for Parkinson's disease. In: Tasker RR, ed. Neurosurgery: State of the Art Reviews. Vol 2(1) Stereotactic Surgery. Philadelphia: Hanley and Belfus, 1987: 209-234.

117. Kelly PJ, Gillingham FJ. The long term results of stereotaxic surgery and L-dopa therapy in patients with Parkinson's disease: a 10-year follow up study. J Neurosurg 1980; 53: 332-337.

118. Benabid AL, Pollak P, Seigneuret E, et al. Chronic VIM thalamic stimulation in Parkinson's disease, essential tremor and extrapyramidal dyskinesias. Acta Neurochir 1993; 58: 39-44.

119. Delong MR. Primate models of movement disorders of basal ganglia origin. Trends Neurosci 1990; 13: 281-285.

120. Bergman H, Wichmann T, Delong MR. Reversal of experimental parkinsonism by lesions of the subthalamic nucleus. Science 1990; 249: 1436-1438.

121. Laitinen LV, Bergenheim T, Hariz MI. Leksell's posteroventral pallidotomy in the treatment of Parkinson's disease. J Neurosurg 1992; 76: 53-61.

122. Svennilson E, Torvik A, Lowe R, et al. Treatment of parkinsonism by stereotactic thermolesions in the pallidal region: a clinical evaluation of 81 cases. Acta Psychiatr Neurol Scand 1960; 35: 358-377.

123. Ceballos-Baumann AO, Obeso JA, Vitek JL, et al. Restoration of thalamocortical activity after posteroventral pallidotomy in Parkinson's disease. Lancet 1994; 344: 814-815.

124. Lozano AM, Lang AE, Galvez-Jimnez N, et al. Effect of Gpi pallidotomy on motor function in Parkinson's disease. Lancet 1995; 346: 1383-1387.

125. Benabid AL. Deep brain stimulation in Parkinson's disease: present state and outlook. Mediview, 4th International Congress of Movement Disorders 1996: 2. 